\title{
DÍVIDA PÚBLICA NO BRASIL: DIAGNÓSTICO E PERSPECTIVAS
}

Felipe Scudeler Salto

Diretor-Executivo da Instituição Fiscal Independente do Senado Federal.

Gabriel Leal de Barros

Economista, Mestre pela EPGE/FGV e ex-Diretor da Instituição Fiscal Independente, do Senado Federal.

\section{SUMÁRIO}

Introdução - 1. Diagnóstico do quadro fiscal brasileiro - 2. Perspectivas para restauração do equilíbrio fiscal - Conclusões - Referências. 


\section{INTRODUÇÃO}

O presente capítulo pretende contribuir para a compreensão do quadro atual das contas públicas brasileiras, sob a ótica da sustentabilidade da dívida pública brasileira. A partir dos diagnósticos econômico-fiscais construídos pela Instituição Fiscal Independente do Senado Federal (IFI) ${ }^{1}$, apresentaremos os desafios que se colocam ao Brasil no sentido de recuperar o equilíbrio fiscal, medido pela trajetória do indicador dívida/PIB. Assim, o texto divide-se em duas seções, além deste tópico introdutório: 1 - Diagnóstico do quadro fiscal brasileiro e 2 - Perspectivas para restauração do equilíbrio fiscal.

A partir das análises elaboradas e disponibilizadas pela IFI em sua página eletrônica, até a data de 22 de agosto de 2018, quando este capítulo está sendo redigido, proporemos uma avaliação geral do quadro fiscal, indicando os entraves à consolidação fiscal e os possíveis meios para superá-los. Analisaremos a evolução das receitas e despesas públicas, indicando, a partir da equação de sustentabilidade da dívida pública, os caminhos para recompor a ordem nos números do governo.

O sistemático e persistente aumento da relação dívida/PIB, desde 2013, teve como principal resposta das autoridades fiscais a adoção do chamado teto para os gastos públicos, fixado pela Emenda Constitucional n. 95, promulgada em 15 de dezembro de $2016^{2}$. Sua adoção foi importante para ancorar as expectativas dos agentes econômicos e explicitar à sociedade e ao Congresso a restrição orçamentária do setor público. Ao limitar a velocidade de crescimento do gasto público primário ou não financeiro (sem incluir juros), principal causa para o desequilíbrio fiscal, espera-se que uma série de reformas estruturais pelo lado da despesa obrigatória sejam conduzidas. Como mostraremos, a discussão sobre os gastos obrigatórios é, atualmente, indissociável do debate sobre o ajuste fiscal.

Nesta seção introdutória, cabe ainda descrevermos o escopo de atuação da nova instituição criada no Brasil, a IFI, no âmbito do Senado Federal, que também surgiu como uma resposta ao grave quadro econômico vivenciado pelo Brasil. Não custa lembrar que a queda acumulada do PIB, entre 2015 e 2016, segundo o IBGE, foi da ordem de $7 \%$, o que configurou um período de recessão profunda, sendo o pior biênio da série histórica.

A IFI foi instalada, em novembro de 2016, a partir da Resolução n. 42/2016², aprovada no mesmo ano pelo Senado. Seu objetivo é ampliar a transparência nas

\footnotetext{
1 Página eletrônica da IFI - https://www12.senado.leg.br/ifi

2 EC n. 95/2016 - http://www.planalto.gov.br/ccivil_03/constituicao/emendas/emc/emc95.htm

3 Resolução n. 42/2016 - https://www12.senado.leg.br/ifi/
} 
contas públicas e contribuir para a disciplina fiscal. Essa ampla assessoria ao Senado, por meio de relatórios, notas técnicas e estudos, de maneira tecnicamente independente, é exercida, hoje, no mundo, por cerca de 40 instituições, a exemplo do Congressional Budget Office (CBO), nos Estados Unidos, do Office for Budget Responsibility (OBR), no Reino Unido, do Conselho de Finanças Públicas (CFP), em Portugal, dentre outras.

A IFI do Senado Federal tem quatro funções básicas definidas em lei e a independência técnica deriva do mandato fixo dos seus três diretores, que são indicados pela Presidência do Senado, pela Comissão de Assuntos Econômicos e pela Comissão de Transparência e Fiscalização, sabatinados e submetidos à aprovação em Plenário:

I - divulgar suas estimativas de parâmetros e variáveis relevantes para a construção de cenários fiscais e orçamentários;

II - analisar a aderência do desempenho de indicadores fiscais e orçamentários às metas definidas na legislação pertinente;

III - mensurar o impacto de eventos fiscais relevantes, especialmente os decorrentes de decisões dos Poderes da República, incluindo os custos das políticas monetária, creditícia e cambial; e

IV - projetar a evolução de variáveis fiscais determinantes para o equilíbrio de longo prazo do setor público (Art. $1^{\circ}$ da Resolução n. 42/2016).

Como se vê, é obrigação da IFI produzir cenários econômicos e fiscais, considerando-se o "equilíbrio de longo prazo do setor público". Nesse sentido, temos produzido o Relatório de Acompanhamento Fiscal (RAF), com periodicidade mensal, onde publicamos nossas projeções para as principais variáveis macroeconômicas, como: PIB, juros, inflação e taxa de câmbio.

A partir disso, traçamos três cenários para as variáveis fiscais, sobretudo o resultado primário e a dívida bruta do governo geral. O resultado primário (RP) pode ser definido como a diferença entre as receitas e despesas públicas, exceto o pagamento de juros sobre a dívida. Já a dívida bruta do governo geral (DBGG) é a soma de todos os passivos do setor público, incluindo a União, os Estados e Municípios, além de uma parte da dívida do Banco Central, as chamadas operações compromissadas (detalhada a seguir) ${ }^{4}$.

Na seção 1, apresentaremos uma análise da evolução desses indicadores, contextualizando a situação das contas públicas brasileiras ao desafio de recupe-

4 Sobre o tema das operações compromissadas, recomendamos a leitura do Estudo Especial n. 03 da IFI - http://www2.senado.leg.br/bdsf/bitstream/handle/id/533520/Estudo_OpCompromissadas.pdf 
rar a sustentabilidade da dívida pública e, assim, abrir espaço para a possibilidade de voltarmos a apresentar taxas de crescimento econômico mais elevadas. Dados comparados ajudarão a compreender a dimensão do ajuste fiscal requerido e a posição relativa do Brasil no rol dos países emergentes e desenvolvidos.

$\mathrm{Na}$ seção 2, discutiremos as possibilidades e alternativas de políticas a serem adotadas para retirar o Brasil do quadro de crescimento da DBGG, hoje em 77\% do PIB, isto é, 24 pontos percentuais (p.p.) acima do nível observado em dezembro de 2013.

Antes de detalhar as seções, é preciso ter claro que o Brasil ainda vive as consequências de um período de forte deterioração das contas públicas - 2009 a 2014 - após uma árdua jornada de construção de regras e de um arcabouço institucional sólido na área das contas públicas. Ainda nos anos 1980, o país criou a Secretaria do Tesouro Nacional para gerir a dívida pública e extinguiu a chamada Conta de Movimento entre Banco do Brasil e Banco Central ${ }^{5}$. Já nos anos 1990 e 2000, o governo promoveu o saneamento e fechamento dos bancos estatais estaduais e estabeleceu diretrizes importantes para as contas públicas, por meio da Lei de Responsabilidade Fiscal ${ }^{6}$.

A utilização de práticas contábeis alternativas, denominada de "contabilidade criativa”, entre 2009 e 20147, turvou a adequada leitura da situação das contas públicas, contribuindo para a deterioração do esforço fiscal para pagar os juros da dívida (i.e., do resultado primário) e das expectativas dos agentes econômicos em torno da posição e evolução da política fiscal. Neste período, por exemplo, a meta de resultado primário passou a ser descontada de investimentos e, em um segundo momento, das desonerações tributárias.

A expansão fiscal autorizada por esse expediente combinou-se com a queda das taxas de crescimento econômico do país, dado o fim do período áureo de

5 Até a criação do Banco Central (BC), em dezembro de 1964, o Banco do Brasil atuava como um Banco Central misto, exercendo atividades tanto de banco comercial como a venda de produtos privados quanto de autoridade monetária através da definição de taxas de redesconto, emissão de moeda e assistente do nível de liquidez. O fornecimento de recursos do BC para compensar os desequilíbrios no ativo e passivo do BB era chamado de "conta movimento". Com a criação do Banco Central, as atividades foram gradativamente segmentadas até que em dezembro de 1984, por decisão do Conselho Monetário Nacional (CMN), a "conta movimento" foi extinta.

6 Para uma compreensão dessa evolução institucional, ver o livro "Finanças públicas: da contabilidade criativa ao resgate da credibilidade" (Salto e Mansueto, 2016), especialmente o capítulo de Maílson da Nóbrega.

7 A esse respeito, recomenda-se a consulta aos trabalhos de Barros e Afonso (2013). 
crescimento dos preços das commodities exportadas pelo Brasil, produzindo dois fenômenos: transformação do superávit primário em déficit e interrupção da trajetória de queda da relação dívida/PIB, com posterior início de um aumento que perdura até hoje. A reversão desse processo não será tarefa fácil.

É preciso ainda compreender que o ajuste fiscal não é um fim em si mesmo, mas um meio através do qual o setor público garante as condições mínimas necessárias para executar suas políticas públicas e garantir ambiente profícuo ao crescimento econômico. Os governos possuem apenas três formas de financiar seus gastos: a primeira, através dos tributos pagos pela sociedade; a segunda, pela emissão de títulos da dívida pública; e, a terceira, por intermédio da emissão de papel moeda pelo Banco Central. É consensual que a sociedade brasileira não suporta mais financiar gastos públicos por meio de inflação, após o Plano Real. De forma semelhante, há intolerância para elevação de carga tributária, de maneira que até o presente momento o desequilíbrio fiscal tem sido financiado pela ampliação da dívida pública. Essa dinâmica, todavia, tem limites em função do risco de se financiar um déficit público substancial na ausência de um plano de consolidação fiscal que seja capaz de reverter o resultado negativo e dar algum horizonte de solvência para o setor público.

É esse o contexto em que apresentamos nosso capítulo, colaborando com este compêndio no sentido de trazer luz sobre os números das finanças públicas. Ter o diagnóstico correto é o primeiro passo para que se possam estabelecer novos compromissos na direção do equilíbrio fiscal, de maior transparência, accountability e respeito ao dinheiro público.

\section{DIAGNÓSTICO DO QUADRO FISCAL BRASILEIRO}

Os principais indicadores utilizados pelos economistas para medir ou avaliar a situação das contas públicas são: o resultado nominal (RN), o resultado primário (RP), a dívida pública bruta (DBGG) e a líquida (DLSP). Há discrepâncias entre alguns dos indicadores calculados e utilizados no Brasil e os internacionalmente aceitos, comumente disponibilizados pelo Fundo Monetário Internacional (FMI) no seu Monitor Fiscal ${ }^{8}$. Entretanto, há convergência em torno dos resultados observados nessas distintas fonte e métodos.

Hoje, por exemplo, o Brasil possui uma dívida bruta elevada e crescente. Em comparação com o nível de endividamento dos países emergentes, o quadro mostra-

8 Para ver a última edição do Monitor Fiscal do FMI, clique aqui - http://www.imf.org/en/publications/fm 
-se ainda mais preocupante. A DBGG, segundo dados do Banco Central do Brasil', é de $77,2 \%$ do PIB (dados de junho de 2018), como já mencionamos. Pelos dados do FMI, a dívida brasileira já atinge $87 \%$ do PIB no mesmo período ${ }^{10}$. Tomando-se a média dos países emergentes e a média dos desenvolvidos, ao longo do tempo, é possível ter uma base para comparação. O gráfico 1 traz essas informações.

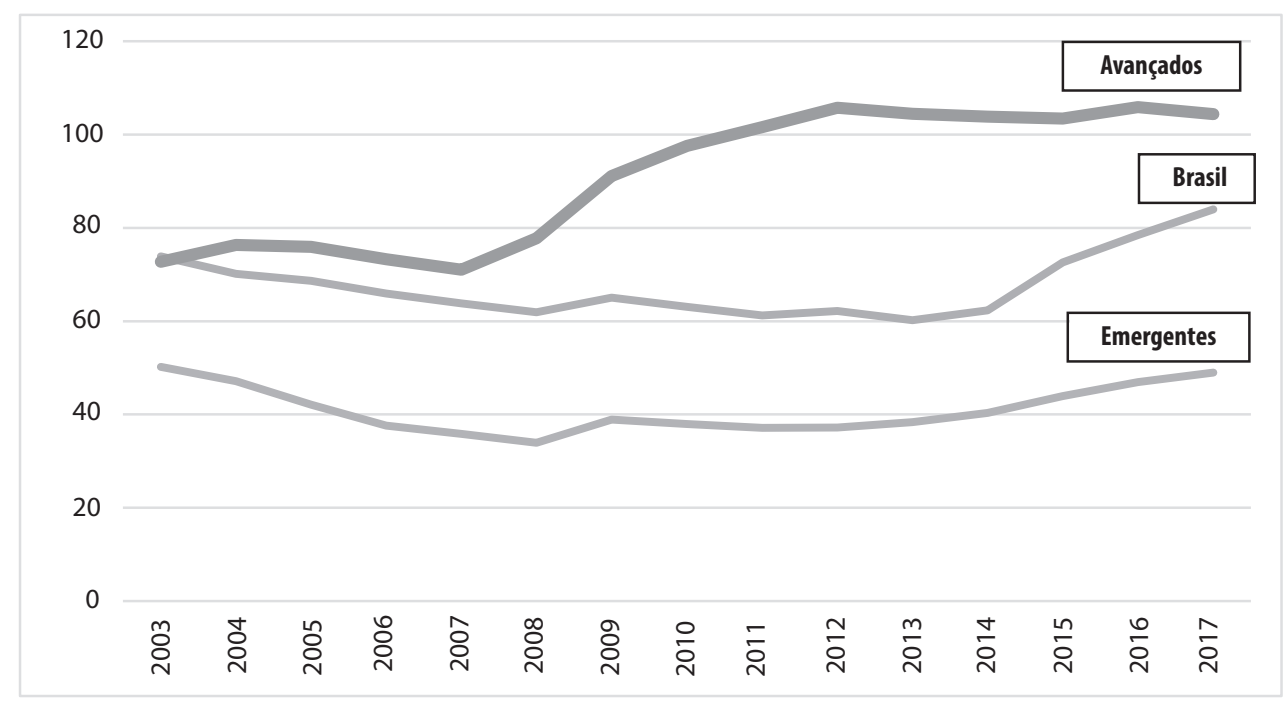

\section{Gráfico 1 - Dívida bruta (conceito FMI) para países emergentes, avançados e Brasil (\% do PIB)}

Fonte: FMI. Elaboração própria.

O gráfico 1 mostra que a trajetória de crescimento da dívida brasileira descolou da dinâmica verificada na média dos países emergentes. Enquanto o nível médio dos emergentes foi inferior a 50\% do PIB em 2017, o Brasil registrou nível bem mais elevado, de $84 \%$ do PIB, cuja expansão tem avançado rapidamente. Se não houver mudanças nos fatores condicionantes dessa dinâmica, a tendência da curva azul, no gráfico 1, é aproximar-se rapidamente do perigoso nível de 100\%

9 Veja a série histórica sob nova metodologia aqui - http://www.bcb.gov.br/htms/infecon/seriehistDLSPBruta2008.asp

10 Estimativas da IFI com base na metodologia do FMI. As estatísticas do FMI possuem um caráter, digamos, mais conservador, pois consideram como dívida pública toda a carteira de títulos sob responsabilidade do Banco Central, tanto os títulos livres quanto as operações compromissadas. Já na metodologia doméstica, apurada pelo Banco Central, a dívida bruta é composta apenas pela carteira de títulos livres, isto é, títulos públicos que não estejam lastreando as operações compromissadas realizadas pelo Banco Central no gerenciamento da quantidade de dinheiro em circulação na economia. Esta é a única diferença entre os indicadores. 
do PIB, bem próximo da média das economias avançadas. Contudo, há uma diferença fundamental relacionada ao custo de rolagem desta dívida: as taxas médias dos títulos brasileiros são substancialmente maiores em razão dos desequilíbrios macroeconômicos.

A esse respeito, vale destacar que a taxa básica de juros (i.e, a taxa Selic), principal referência para o custo de rolagem da dívida pública, não é causa e sim consequência dos fundamentos macroeconômicos do país, como seu nível de poupança, grau de indexação, desequilíbrio das contas fiscais, demografia, dentre outros. Particularmente em relação à poupança, países que apresentam baixo nível de poupança doméstica precisam de capital externo para financiar seus investimentos.

No caso do governo, que gasta mais do que arrecada, sua taxa de poupança é negativa. O ambiente de negócios, regime tributário e regulatório afetam ainda a poupança e investimento por parte das empresas. A demografia também é importante, uma vez que países mais idosos poupam menos do que países mais jovens. Em suma, estas e outras variáveis que espelham o fundamento macroeconômico do país, influenciam a formação da taxa de juros.

Uma taxa de juros mais ou menos elevada nos leva a discutir a chamada equação de sustentabilidade da dívida pública. Como se sabe, a dívida pública se faz necessária para que o governo possa financiar despesas não cobertas pelas receitas públicas, isto é, pela arrecadação de impostos, taxas, multas e contribuições. Essa diferença entre receitas e despesas totais denomina-se resultado nominal. Quando positivo, chamamos de superávit nominal e, quando negativo, déficit nominal. O Brasil, hoje, possui um déficit nominal da ordem de R $\$ 487$ bilhões ou 7,3\% do PIB (dados acumulados em 12 meses findos em junho de 2018).

A geração de déficits demanda que seu financiamento ocorra através da emissão de títulos públicos como forma de o governo obter recursos privados que deverão ser pagos em períodos posteriores, movimento que eleva a dívida pública. ${ }^{11}$ Esse é o mecanismo por trás do financiamento e funcionamento da política

11 Aqui, é importante destacar a exata relação entre os déficits públicos e a dívida. Na verdade, o déficit nominal impacta diretamente a chamada Dívida Fiscal Líquida (DFL), indicador divulgado também pelo Banco Central. A Dívida Líquida do Setor Público (DLSP) é influenciada por outros fatores, como os efeitos do câmbio sobre as reservas internacionais, que distanciam os dois indicadores - DLSP e déficit nominal. Também a DBGG não guarda relação direta com o déficit nominal, uma vez que sua construção considera a totalização apenas dos passivos do setor público, de tal sorte que a variação do estoque da DBGG não equivale ao déficit nominal. Evidentemente, o déficit nominal e a DBGG estão correlacionados, mas é importante que se tenha em tela a existência de discrepâncias contábeis e de definição que acabam impedindo o estabelecimento de uma relação direta entre essas variáveis. Para uma análise detalhada da DFL, vale a consulta deste artigo de Josué Pellegrini -http://www.brasil-economia-governo.org.br/2013/10/14/divida-liquida-do-setor-publico-decrescente-significa-politica-fiscal-sob-controle/ 
fiscal. O mais importante, como se vê, não é buscar anular a dívida pública, mas, sim, construir as condições macroeconômicas suficientes para ter dívida menos custosa e sustentável para o Erário. Isso só se obtém na presença de um governo probo e eficiente, como discutiremos.

A equação de sustentabilidade ajuda a compreender a relação entre os resultados fiscais e a trajetória da dívida. Ela relaciona a variação da dívida, do lado esquerdo da equação, com o resultado primário, a taxa de juros reais, o crescimento econômico e o estoque da própria dívida. ${ }^{12}$

Objetivamente, a equação de sustentabilidade da dívida bruta pode ser feita simplificadamente da seguinte forma:

$$
\Delta D=d p+(j-c) * D, \text { onde: }
$$

$\Delta \mathrm{D}$ é a variação da dívida em percentual do PIB; dp é o déficit primário, em percentual do PIB; j é a taxa real média de juros da dívida bruta; c é a taxa real de crescimento do PIB e D é o estoque da dívida bruta em percentual do PIB.

Essa equação mostra que a dívida cresce $(\Delta \mathrm{D}>0)$ quando há déficit primário. Ela também aumenta quando a diferença entre os juros reais e o crescimento do PIB é positiva. Sendo assim, podemos calcular, para dados crescimento do PIB, juro real e estoque de dívida bruta, o resultado primário necessário para estabilizar a relação dívida/PIB, isto é, para que $\Delta \mathrm{D}$ seja igual a zero.

Por exemplo, se o PIB do Brasil crescer, em média, 2,0\% em termos reais, nos próximos anos, a taxa real de juros (taxa de juros nominal esperada para doze meses à frente, descontada a expectativa de inflação) ficar na casa de $4 \%$ e o estoque da dívida no período anterior for de $85 \%$ do PIB, temos, para que a dívida fique estável em relação ao PIB (isto é, $\Delta \mathrm{D}=0$ ):

$$
\begin{aligned}
0=d p+ & (4,0 \%-2,0 \%) * 85 \text { e, rearranjando: } \\
& -d p+2,0 \% * 85 \\
\mathrm{dp}= & -1,7(\text { sinal negativo }=\text { superávit })
\end{aligned}
$$

Assim, seria preciso um superávit primário ${ }^{13}$ de $1,7 \%$ do PIB para estabilizar uma dívida bruta de $85 \%$ do PIB, isto é, para que ela parasse de crescer. Essa é uma forma de mostrar o tamanho do desafio fiscal que se coloca para o país. Atualmen-

12 Para uma explanação sobre a equação de sustentabilidade da dívida, recomenda-se a leitura do capítulo 6 do livro de Macroeconomia dos autores Carlin \& Soskice (2006). Ver referências bibliográficas.

${ }^{13}$ Lembrando que a variável dp representa o déficit primário, isto é, quando dp $>0$, isso representa um déficit primário; quando $\mathrm{dp}<0$, trata-se de superávit primário. 
te, como o déficit primário está em torno de 1,3\% do PIB - e assumindo, por hipótese, que ele seja mantido nesse patamar, isto é, que não piore - a dimensão do ajuste é de algo como $3 \%$ do PIB $(1,7 \%+1,3 \%)$. Em reais, se tomarmos como base o PIB nominal de 2023, incorporadas projeções feitas pela IFI $^{14}$, trata-se de um ajuste de mais de $\mathrm{R} \$ 350$ bilhões de reais a ser implementado até o final de $2023^{15}$.

A questão central, portanto, não é sobre a necessidade de se fazer um relevante e factível programa de consolidação fiscal, algo imperativo quando considerados os cálculos ora apresentados. O fundamental é como o ajuste será endereçado do ponto de vista de sua composição entre medidas pelo lado do gasto e da receita, qual o espaço fiscal existente para promover as mudanças no pouco tempo disponível e se a economia política do país conseguirá compreender e aprovar as medidas necessárias para pavimentar o reequilíbrio das finanças públicas.

O setor público consolidado possui, atualmente, um déficit nominal de $7,28 \%$ do PIB, composto por 1,34\% do PIB de déficit primário e 5,94\% do PIB em pagamento líquido de juros sobre a dívida. A evolução dessas variáveis pode ser vista no gráfico 2 .

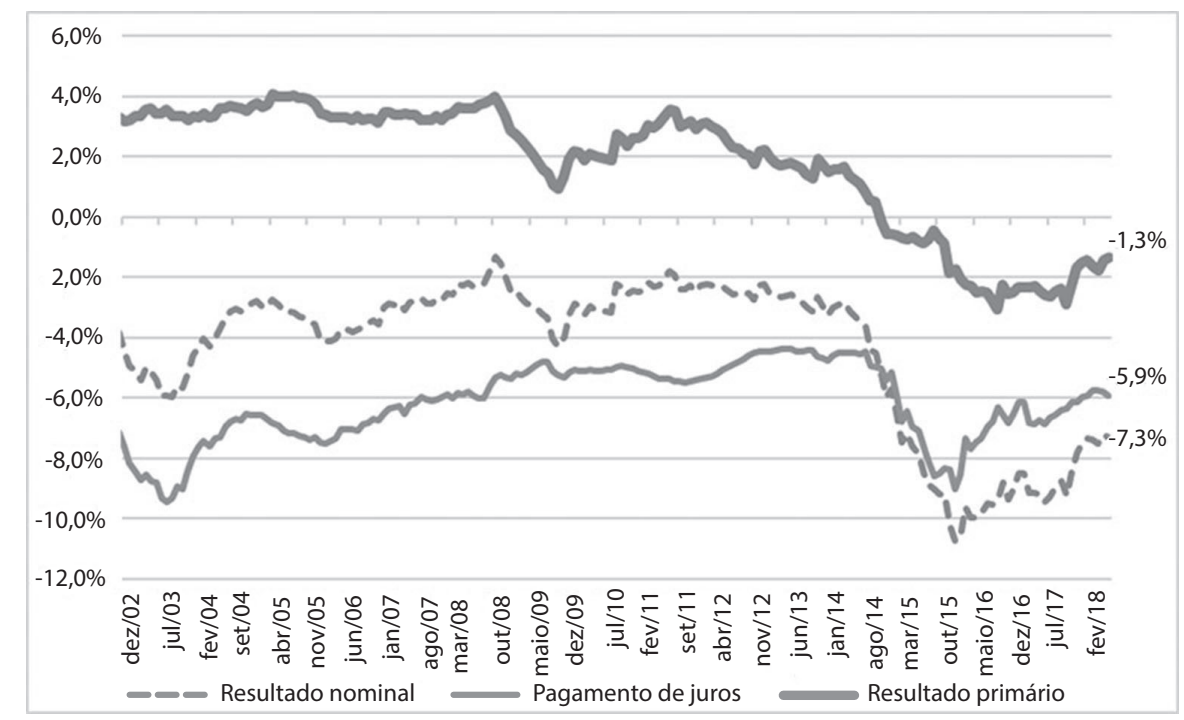

Gráfico 2 - Evolução do resultado nominal, resultado primário e pagamento de juros (\% do PIB) - acumulado em 12 meses

Fonte: Banco Central. Elaboração própria.

14 Acesse o banco de dados e projeções da IFI no endereço - https://www12.senado.leg.br/ifi/dados/dados

15 A data de 2023 foi escolhida porque, segundo os cenários prospectivos da IFI, o quadro de maior probabilidade indica que a dívida será estabilizada apenas em 2023 em um nível próximo do considerado no exercício apresentado neste capítulo. 
O gráfico 2 permite observar que a deterioração do resultado primário começou a ocorrer a partir de 2009, com reversão pontual em 2010/11. A partir de 2009, três fatores foram preponderantes para explicar essa dinâmica: i) crescimento mais acelerado da despesa primária do governo central; ii) queda da arrecadação em decorrência de desonerações tributárias crescentes; e iii) reflexos do início do processo de intervenção em diversos setores da economia, como o energético e o petrolífero. O novo arranjo de política econômica iniciado em 2009 e aprofundado a partir de 2012 produziu notáveis efeitos colaterais negativos sobre o ritmo de crescimento da economia e, consequentemente, sobre o fôlego da arrecadação.

O embrião do processo de deterioração das contas públicas, no entanto, nasceu antes, ainda em 2008, em resposta aos efeitos da crise financeira internacional ou à adoção de uma política chamada de "anticíclica". O regime de metas para o resultado primário, instituído ao final da década de 90 , passou a ter menor importância relativa dentro da institucionalidade fiscal do país. O modelo fiscal consagrado na Lei de Responsabilidade Fiscal (LRF), em maio de 2000, foi sendo gradativamente flexibilizado por meio da permissão para abatimentos da meta de resultado primário. Investimentos, no primeiro momento, e subsídios habitacionais e desonerações tributárias, posteriormente. $\mathrm{O}$ resultado desse experimentalismo foi uma perda da âncora fiscal para os agentes econômicos, seguida de longo período de expansão fiscal.

Em 2009, em artigos publicados na imprensa, já alertávamos para o risco de adoção dessa estratégia para a sustentabilidade das contas públicas ${ }^{16}$. Com o excesso de discricionariedade na definição dos abatimentos da meta de resultado primário, a âncora fiscal perdeu importância relativa como sinal de saúde das contas públicas. Inicialmente, um pequeno volume de gastos do chamado Projeto Piloto de Investimentos (PPI) foi deduzido e, posteriormente, foram feitos novos descontos relativos aos investimentos do Programa de Aceleração de Crescimento (PAC). As deduções continuaram a crescer com a inclusão de subsídios do Programa Minha Casa Minha Vida (MCMV), desonerações tributárias e, em seguida, de frustração de determinadas receitas ${ }^{17}$.

Em perspectiva mais ampla, no entanto, é preciso considerar que o avanço do gasto público ${ }^{18}$ é anterior aos anos 2000. A Constituição de 1988 impôs um conjun-

16 Para maiores detalhes, ver artigo para o jornal O Estado de S. Paulo - "Contabilidade criativa turva meta fiscal”, de Maílson da Nóbrega e Felipe Salto (2009) nas referências bibliográficas.

17 Para uma análise pormenorizada dessa questão, ver Barros (2017) nas referências bibliográficas.

${ }_{18} \mathrm{Na}$ verdade, há uma discussão teórica e empírica importante sobre a classificação da política fiscal. A variável mais importante para medir o grau de expansão é o chamado impulso fiscal. O impulso é calculado pela variação do resultado primário estrutural, isto é, do resultado primário recorrente (quando descontados eventos atípicos e extraordinários na receita e na despe- 
to de direitos aos cidadãos e deveres ao Estado que demandou um forte crescimento da carga tributária para o seu financiamento. Nos primeiros 20 anos, de 1988 até 2008, a tendência da série de carga tributária foi claramente de alta. A partir de 2009, uma série de renúncias de receitas foram instituídas como forma de amortecer os efeitos da crise financeira internacional e houve recuo importante no ritmo de crescimento da arrecadação, em razão da malsucedida intervenção na economia, a cunha fiscal parou de subir e tem apresentado gradual recuo (gráfico 3)

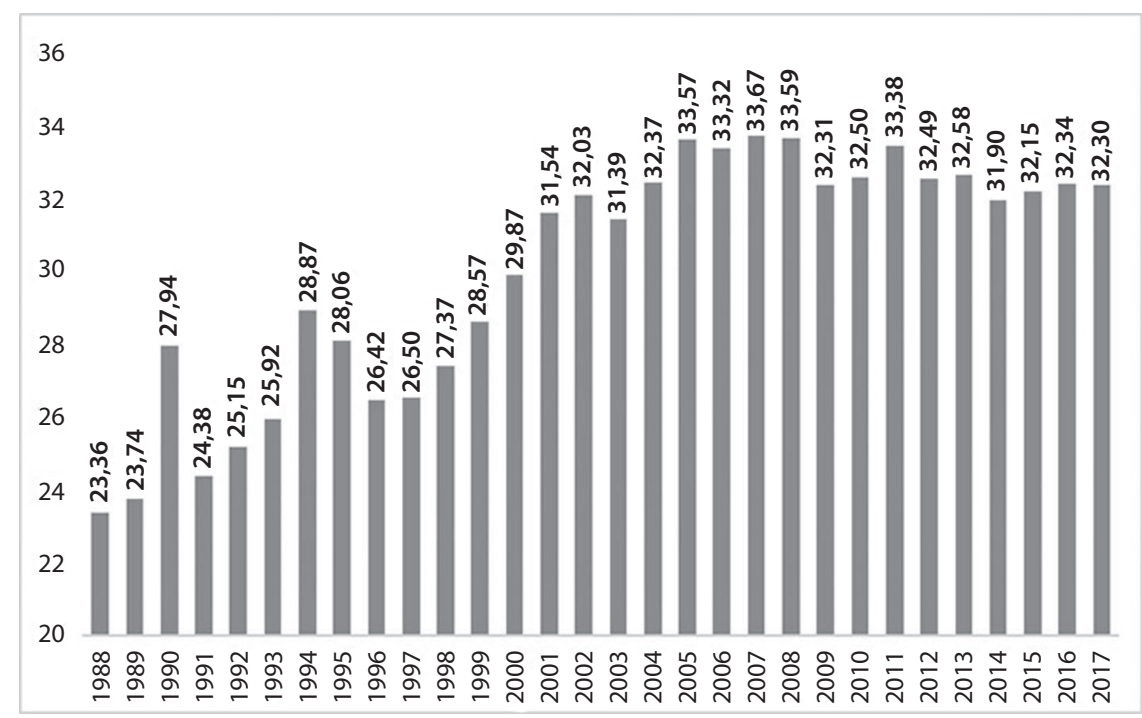

\section{Gráfico 3 - Evolução da carga tributária brasileira (\% do PIB)}

Fonte: Instituição Fiscal Independente (IFI) do Senado Federal.

O avanço da carga tributária, seja por elevações de alíquotas seja como decorrência da maior formalização no mercado de trabalho ou do crescimento econômico, não foi suficiente, conforme destacamos nos parágrafos anteriores, para evitar a geração de déficits primários. Isso porque, além da pressão estrutural por aumento de gastos, uma série de decisões legais tomadas por distintos governos contribuíram para robustecer a velocidade de crescimento das despesas públicas. No período pós-crise, além desta pressão estrutural, novas despesas foram criadas como, por exemplo, os Programas Minha Casa Minha Vida (MCMV) e de Sustentação do Investimento (PSI), a desoneração da folha de pagamentos, os subsídios educacionais via FIES e as subvenções energéticas, dentre outros.

sa, como as receitas de programas especiais de parcelamento de dívida ("Refis") ou uma despesa temporária como a ajuda financeira ao estado do RJ) ajustado pelos efeitos do ciclo de atividade econômica. Para uma abordagem completa, ver Barros (2017). 
Vale notar que não estamos apresentando, aqui, uma avaliação do mérito das propostas, mas tão somente de seu impacto e contribuição no processo de deterioração fiscal verificado no período recente. O resultado de despesas estruturalmente elevadas e de novos gastos criados a partir de 2009 (detalhado em seguida), somado ao elevado volume de renúncias fiscais instituídas, antecipou o aprofundamento do desequilíbrio fiscal. De 1998 a 2017, as despesas primárias do governo federal tiveram crescimento médio de $5,4 \%$ ao ano, enquanto o PIB cresceu $2,3 \%$ ao ano.

Com a carga tributária virtualmente estabilizada e apresentando, inclusive, uma queda gradual, o avanço da despesa acima do PIB precisou ser financiado de alguma forma: além da inflação persistentemente elevada e próxima do teto da meta de $6,5 \%$ ao ano, houve aumento expressivo da dívida pública. Apesar de o gráfico da dívida bruta no conceito internacional já ter sido apresentado anteriormente, é importante analisar os detalhes. Para tanto, levando em consideração a metodologia do Banco Central, é possível identificar que os dois principais componentes da dívida bruta são as chamadas operações compromissadas e a dívida mobiliária do governo federal.

Quanto ao perfil do endividamento público brasileiro, os dados mostram que ele é particularmente marcado por duas características: prazo médio curto, em torno de quatro anos, e indexação elevada à taxa Selic. O gráfico 4 permite avaliar a evolução dos principais componentes da dívida pública, incluindo as operações compromissadas.

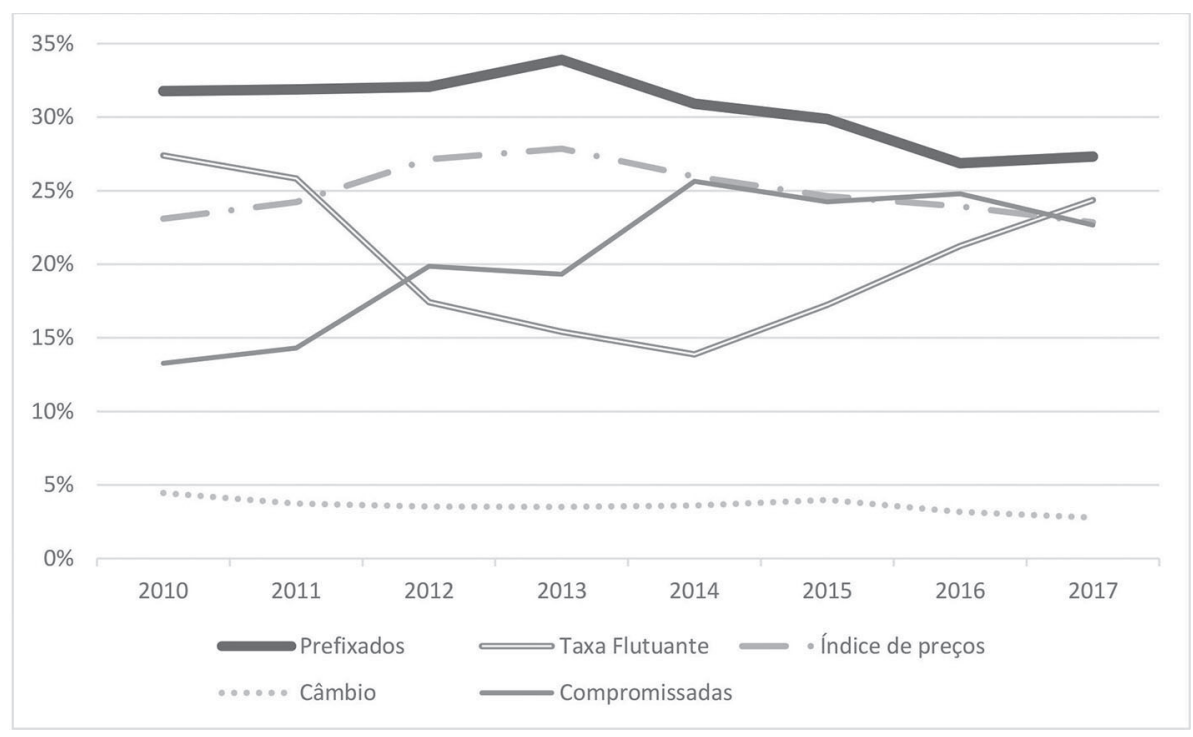

\section{Gráfico 4 - Evolução dos principais componentes da dívida pública (\% da dívida total)}

Fonte: Banco Central e Tesouro Nacional. Elaboração própria. 
A participação dos títulos indexados à Selic ou de taxa flutuante, como são conhecidos e classificados pelo Tesouro, reduziu-se fortemente, entre 2010 e 2014, tendo passado de $27,4 \%$ da dívida pública mobiliária total (incluindo no denominador as operações compromissadas) para 13,9\%. No mesmo período, no entanto, as operações compromissadas do Banco Central saltaram de 13,3\% para $25,6 \%$ da dívida total. Houve, portanto, uma evidente substituição de títulos atrelados à Selic por compromissadas.

A esse respeito, vale notar ainda que as operações compromissadas são o principal instrumento pelo qual a autoridade monetária controla o nível de liquidez da economia. Nesse sentido, quando há maior liquidez, por exemplo, em razão da acumulação de reservas internacionais, é preciso esterilizar esse aumento de liquidez. A política de reservas, portanto, deve ser levada em conta nas avaliações em torno da composição e perfil do endividamento público.

De 2014 a 2017, os títulos de taxa flutuante saltaram dos 13,9\% para 24,4\%, enquanto as operações compromissadas apresentaram leve recuo, de 25,6\% para $22,7 \%{ }^{19}$. Já os títulos atrelados a índices de preços têm oscilado em torno de um quarto da dívida total, após ensaiar movimento de alta até 2013. Finalmente, os prefixados chegaram a atingir quase 35\% (2013), mas reduziram-se para níveis mais próximos a $27 \%$.

Esses números mostram que o perfil da dívida pública brasileira não tem melhorado nos últimos anos. Os títulos de taxa flutuante, atrelados à Selic, também conhecidos como pós-fixados, são papéis cuja remuneração depende do nível da taxa básica de juros definida pelo Banco Central. Já os prefixados são papeis cuja taxa de juros é determinada previamente e os títulos atrelados a índices de preços respondem às mudanças na inflação.

As operações compromissadas, por sua vez, são títulos prefixados, mas com prazo muito curto, em média inferior a um mês, o que as torna fiscal e economicamente muito parecidas com os títulos indexados à Selic. Para gerenciar a liquidez da economia, o Banco Central realiza operações compromissadas. O "compromisso" se dá no sentido de recomprar em um prazo determinado um título para um agente do mercado. Os títulos são emitidos pelo Tesouro ao Banco Central ${ }^{20}$. Essas operações têm o objetivo de garantir que não haja excesso de títulos ou de dinhei-

19 Quando há maior percepção de risco e incerteza, é esperado que os agentes de mercado tenham maior preferência por títulos de perfil curto e taxa flutuante.

20 A Lei de Responsabilidade Fiscal - Lei Complementar n. 101/2000 - proibiu que o Banco Central emitisse títulos próprios, ficando o Tesouro exclusivamente responsável pela emissão de 
ro no mercado, a ponto de os juros praticados se distanciarem, para cima ou para baixo, da meta fixada pelo Banco Central para a taxa Selic. Vale lembrar que a meta-Selic tem por objetivo balizar o custo do crédito no país e garantir, assim, o cumprimento de uma determinada meta de inflação. ${ }^{21}$

Quando há excesso de moeda em circulação e o Banco Central observa que os juros praticados com títulos públicos no mercado estão abaixo da meta-Selic, ele faz operações compromissadas de venda de títulos, retirando o excesso de dinheiro da economia em troca de um compromisso de pagar juros mais altos para os agentes de mercado e, assim, fazendo o juro médio de todo o sistema voltar a subir, convergindo para a meta-Selic. Quando há escassez de liquidez na economia e os juros estão muito altos, acima da meta-Selic, o Banco Central deixa que as operações compromissadas vençam, ampliando assim a quantidade de dinheiro em circulação e permitindo que os juros médios do sistema diminuam, convergindo novamente para a meta-Selic. ${ }^{22}$

Por essas razões, os juros das operações compromissadas sempre tendem a aproximar-se da própria Selic, razão pela qual essa parcela da dívida pública deve ser analisada conjuntamente com os títulos pós-fixados, isto é, os títulos indexados à Selic ou de taxa flutuante. O grau de substituição entre eles é elevado, como se pode concluir, já que na ausência de um deles, o outro oferece condições muito similares para um eventual tomador: prazo curto e remuneração atrelada à Selic.

O desejo do mercado por títulos com esse perfil está condicionado às suas perspectivas a respeito da economia e das contas públicas. Se o governo é bom pagador e tem um risco de crédito baixo, apresenta bons fundamentos econômicos, tais como: crescimento econômico e déficits públicos baixos ou até mesmo superávits. Nesse contexto, é consequência natural o maior apetite por títulos emitidos pelo Tesouro para prazos mais longos, com juros mais baixos.

títulos públicos, incluindo títulos a serem entregues ao Banco Central para realização de suas operações típicas de controle de liquidez.

21 Para uma compreensão plena do regime de metas para a inflação, adotado em 1999 no Brasil, acessar o texto para discussão de Bogdanski et al (2000) em - https://www.bcb.gov.br/pec/wps/ ingl/wps01.pdf

22 Esses mecanismos estão bem descritos em box do Relatório de Acompanhamento Fiscal da IFI publicado neste link - http://www2.senado.leg.br/bdsf/bitstream/handle/id/529486/RAF_ abr17_pt3.pdf? sequence $=10$ 
Por outro lado, se o governo tem contas desarrumadas e não sinaliza mudanças críveis em horizonte relevante, é igualmente natural que o mercado tenha maior interesse e apetite em financiar os déficits públicos se a remuneração for mais elevada e de prazo mais curto. Quanto maior a incerteza sobre as contas públicas e o risco de pagamento de crédito, menor a disposição por comprar títulos longos e com taxa pré-definida.

Do ponto de vista do governo, o ideal é ter prazo longo e juros baixos. Essa combinação permite que menos recursos sejam anualmente comprometidos com pagamento do serviço da dívida, abrindo espaço fiscal para redução mais acelerada da dívida pública e, futuramente, maior fôlego fiscal para execução de políticas públicas. Prazos curtos e juros altos implicam alto grau de comprometimento do orçamento com o serviço da dívida, sobrando menos espaço fiscal para financiar as políticas de saúde, educação, segurança etc.

Diante o exposto, pode-se concluir que o perfil de endividamento público no Brasil ainda é ruim e muito dependente da evolução da taxa Selic, uma vez que $47 \%$ da dívida correspondem a títulos de taxa flutuante ou operações compromissadas. A condição necessária para alterar esse quadro dependerá da capacidade do país de voltar a gerar superávits primários suficientemente elevados para estabilizar a relação dívida/PIB. Quando os agentes econômicos enxergarem que a probabilidade desse cenário de recuperação do equilíbrio fiscal se tornou mais provável do que um quadro de crescimento sistemático da dívida, como vemos atualmente, então haverá maior espaço para melhorar o perfil da dívida.

Em outras palavras, haverá espaço para uma maior fatia de títulos prefixados, com taxas que sejam vantajosas para o Erário. Quanto maior o horizonte e confiança em torno da solvência da dívida, menores as taxas de juros e maior o prazo para rolar títulos públicos. Hoje, ofertar títulos prefixados é caro para o Tesouro, porque o mercado exige uma taxa de juros muito alta (em razão da maior incerteza) para abrir mão de comprar um título atrelado à Selic, do qual pode se livrar a qualquer momento e no qual a remuneração apresenta elevada liquidez. Comprar um título prefixado com juros reduzidos é o mesmo que dizer para o governo: "eu acredito que você é um bom pagador e seu risco fiscal diminuirá ao longo do tempo". Atualmente, estamos distantes de um quadro como esse.

Antes de avançarmos para a seção de perspectivas para a restauração do equilíbrio das contas públicas, é importante destacar outra característica das con- 
tas públicas brasileiras. Além da baixa qualidade do perfil de endividamento e da carga tributária elevada, o país é marcado por um padrão ruim de composição do gasto público. Os investimentos públicos são baixos e os gastos com pessoal e previdência ocupam fatia expressiva da despesa pública. Esse quadro motivou o governo federal, em 2016, a apresentar uma proposta para limitar o crescimento dos gastos públicos, o chamado teto de gastos. A tabela 1 traz a composição da despesa pública federal segundo seus principais componentes:

Tabela 1 - Evolução dos principais componentes do gasto público federal (\% do PIB) ${ }^{23}$

\begin{tabular}{|c|c|c|c|c|c|c|c|c|c|c|c|}
\hline $\begin{array}{l}\text { Período/ } \\
\text { Rubricas }\end{array}$ & Pessoal & RGPS & FAT & BPC & $\begin{array}{c}\text { Bolsa } \\
\text { Família }\end{array}$ & Subsídios & Discricionárias & Custeio & PAC & Outras & Tota \\
\hline 1997 & 4,2 & 4,9 & 0,5 & 0,0 & 0,0 & 0,2 & 3,9 & 0,3 & & & 14,0 \\
\hline 1998 & 4,5 & 5,3 & 0,4 & 0,0 & 0,0 & 0,2 & 4,1 & 0,3 & & & 14,8 \\
\hline 1999 & 4,4 & 5,4 & 0,4 & 0,0 & 0,0 & 0,2 & 3,6 & 0,5 & & & 14,6 \\
\hline 2000 & 4,5 & 5,5 & 0,4 & 0,0 & 0,0 & 0,2 & 3,7 & 0,4 & & & 14,8 \\
\hline 2001 & 4,8 & 5,7 & 0,4 & 0,0 & 0,0 & 0,3 & 4,1 & 0,3 & & & 15,6 \\
\hline 2002 & 4,8 & 5,9 & 0,5 & 0,0 & 0,0 & 0,1 & 4,2 & 0,3 & & & 15,9 \\
\hline 2003 & 4,5 & 6,2 & 0,5 & 0,3 & 0,0 & 0,3 & 3,1 & 0,3 & & 0,0 & 15,1 \\
\hline 2004 & 4,3 & 6,4 & 0,5 & 0,4 & 0,2 & 0,2 & 3,3 & 0,3 & & 0,0 & 15,6 \\
\hline 2005 & 4,3 & 6,7 & 0,5 & 0,4 & 0,3 & 0,4 & 3,2 & 0,3 & & 0,1 & 16,4 \\
\hline 2006 & 4,4 & 6,9 & 0,6 & 0,5 & 0,3 & 0,3 & 3,2 & 0,3 & & 0,3 & 16,8 \\
\hline 2007 & 4,3 & 6,8 & 0,7 & 0,5 & 0,3 & 0,3 & 3,0 & 0,3 & 0,3 & 0,3 & 16,9 \\
\hline 2008 & 4,3 & 6,4 & 0,7 & 0,5 & 0,3 & 0,1 & 2,8 & 0,3 & 0,4 & 0,4 & 16,2 \\
\hline 2009 & 4,6 & 6,7 & 0,8 & 0,6 & 0,4 & 0,1 & 2,9 & 0,4 & 0,5 & 0,3 & 17,4 \\
\hline 2010 & 4,3 & 6,6 & 0,8 & 0,6 & 0,4 & 0,2 & 2,9 & 0,4 & 0,5 & 0,4 & 17,1 \\
\hline
\end{tabular}

${ }^{23}$ Os gastos com subsídios contemplam, além do programa de sustentação do investimento (PSI) e de subsídios do agronegócio, do setor elétrico e habitacionais com o Programa MCMV, despesas com a compensação pela desoneração da folha de pagamento e outros. Os investimentos do PAC, por sua vez, não contemplam os subsídios do MCMV. Os gastos discricionários não contemplam as despesas com o programa bolsa família. 


\begin{tabular}{|c|c|c|c|c|c|c|c|c|c|c|c|}
\hline 2011 & 4,1 & 6,4 & 0,8 & 0,6 & 0,4 & 0,3 & 2,9 & 0,4 & 0,5 & 0,3 & 16,8 \\
\hline 2012 & 3,9 & 6,6 & 0,8 & 0,6 & 0,4 & 0,4 & 2,8 & 0,5 & 0,6 & 0,3 & 16,9 \\
\hline 2013 & 3,8 & 6,7 & 0,8 & 0,6 & 0,5 & 0,7 & 2,8 & 0,4 & 0,6 & 0,3 & 17,3 \\
\hline 2014 & 3,8 & 6,8 & 0,9 & 0,7 & 0,5 & 0,8 & 3,0 & 0,5 & 0,7 & 0,3 & 18,1 \\
\hline 2015 & 4,0 & 7,3 & 0,8 & 0,7 & 0,5 & 1,7 & 2,8 & 0,8 & 0,4 & 0,5 & 19,4 \\
\hline 2016 & 4,1 & 8,1 & 0,9 & 0,8 & 0,5 & 0,8 & 3,2 & 0,6 & 0,5 & 0,4 & 20,0 \\
\hline 2017 & 4,3 & 8,5 & 0,8 & 0,8 & 0,4 & 0,6 & 2,8 & 0,5 & 0,4 & 0,4 & 19,5 \\
\hline $\mathbf{2 0 1 7 - 1 9 9 7}$ & $\mathbf{0 , 1}$ & $\mathbf{3 , 6}$ & $\mathbf{0 , 4}$ & $\mathbf{0 , 8}$ & $\mathbf{0 , 4}$ & $\mathbf{0 , 4}$ & $\mathbf{- 1 , 1}$ & $\mathbf{0 , 2}$ & $\mathbf{0 , 4}$ & $\mathbf{0 , 4}$ & $\mathbf{5 , 5}$ \\
\hline $\mathbf{2 0 1 6 - 1 9 9 7}$ & $\mathbf{- 0 , 1}$ & $\mathbf{3 , 2}$ & $\mathbf{0 , 4}$ & $\mathbf{0 , 8}$ & $\mathbf{0 , 5}$ & $\mathbf{0 , 6}$ & $\mathbf{- 0 , 7}$ & $\mathbf{0 , 4}$ & $\mathbf{0 , 5}$ & $\mathbf{0 , 4}$ & $\mathbf{6 , 0}$ \\
\hline
\end{tabular}

Fonte: Tesouro Nacional. Elaboração própria.

Como se pode observar, a previdência (8,5\% do PIB em 2017), os gastos com salários dos servidores públicos federais (4,3\% do PIB), o custeio do abono e do seguro-desemprego pelo Fundo de Amparo ao Trabalhador - FAT (0,8\% do PIB) e o Benefício de Prestação Continuada - BPC (0,8\%) representam, juntos, 14,5\% do PIB, em um total de gastos primários de 19,5\% do PIB. Ou seja, apenas essas quatro rubricas consomem cerca de $75 \%$ do gasto público não financeiro. Os investimentos, por sua vez, tomando o PAC como base, figuram na casa de $0,5 \%$ do PIB.

Mas se a fotografia é ruim, o filme dos gastos públicos brasileiros é ainda pior. Quando tomamos as principais despesas federais primárias, entre 2008 e 2017, observamos que a previdência social teve um incremento de 2,2 pontos percentuais do PIB, no período, enquanto a saúde e a educação, juntas, cresceram menos de 1 ponto percentual (p.p.) do PIB. Os gastos com defesa nacional, por exemplo, aumentaram apenas 0,4 p.p. do PIB. Essa tendência permanecerá, caso uma ampla reforma do gasto obrigatório não seja conduzida no Brasil. Esse é um diagnóstico cada vez mais claro, sobretudo diante da evolução demográfica do país.

Tomando-se as novas projeções populacionais do IBGE (Gráfico 5), deste ano, a razão de dependência, medida através da divisão do número de jovens de 15 a 64 anos sobre o número de idosos com idade a partir de 65 anos, sairá de pouco mais de 9 em 2010 e 7,5, em 2018, para apenas 5, em 2030, e pouco mais de 2 jovens por idoso em 2060. O processo de envelhecimento populacional, 
como se vê, será extremamente rápido e imporá desafios ainda mais substanciais par ao custeio da previdência caso não sejam atualizadas as regras de elegibilidade para concessão dos benefícios.
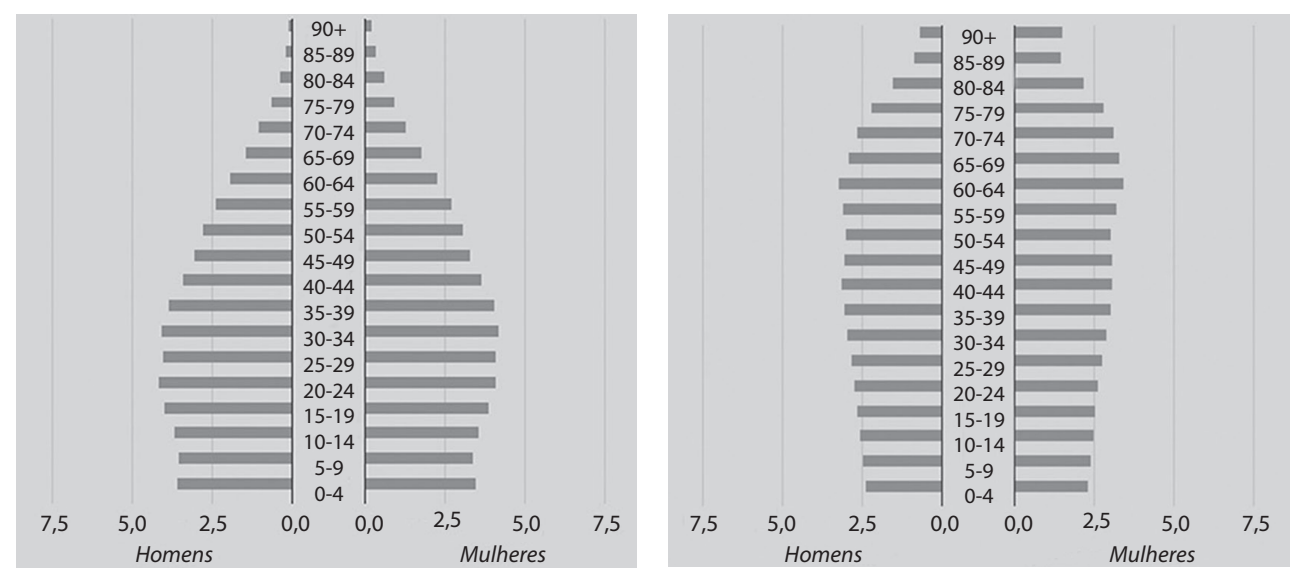

\section{Gráfico 5 - Pirâmide populacional brasileira em 2010 e em 2060 (\%)}

Fonte: IBGE.

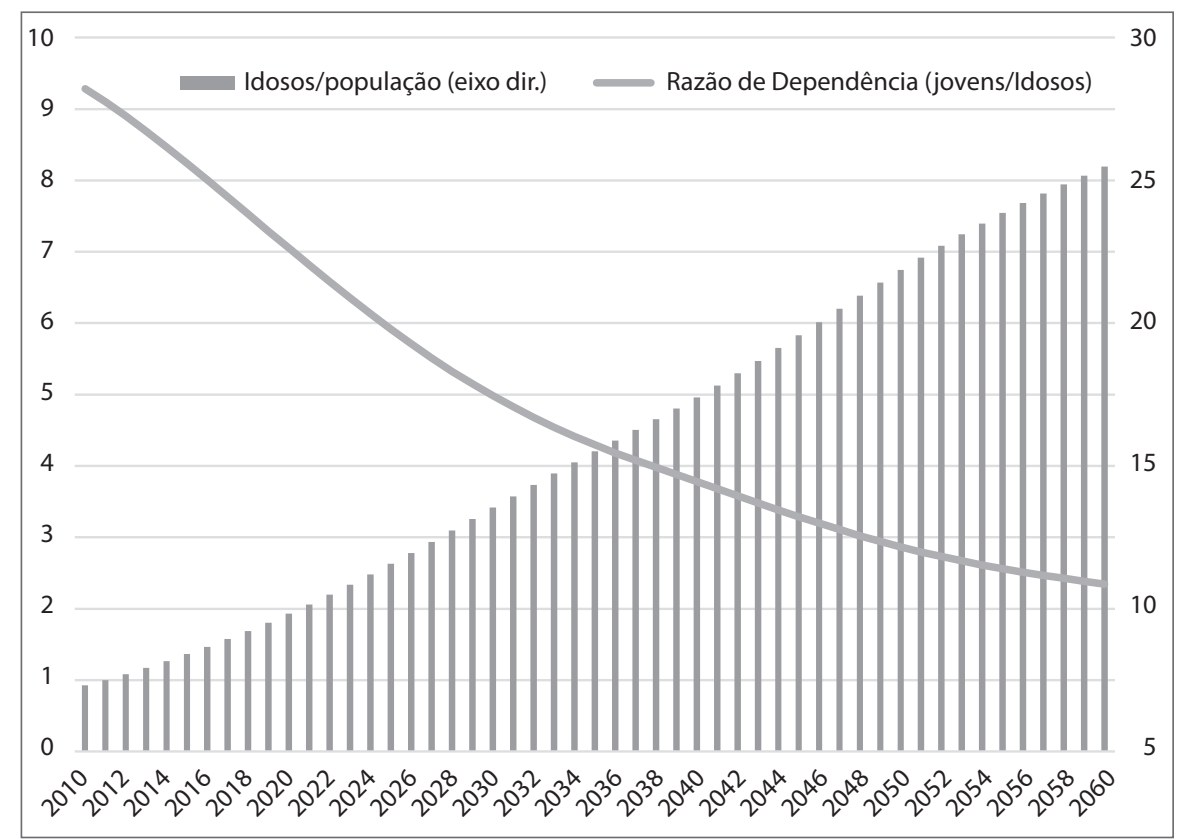

\section{Gráfico 6 - Evolução de Indicadores Demográficos Selecionados}

Fonte: IBGE. Elaboração: IFI. 
Como o sistema previdenciário do RGPS é de repartição, onde cada trabalhador ativo paga o benefício do idoso, a rápida redução da razão de dependência é um grande desafio fiscal e social para o país. O Gráfico 6 revela que a proporção de idosos na população do país saltará de algo em torno de $9 \%$ (ou pouco mais de 19 milhões), em 2018, para cerca de 26\% (ou quase 60 milhões) em 2060. Em relação à projeção anterior do IBGE, o fim do período de crescimento do número de pessoas em idade de trabalhar como proporção da população total (i.e, o chamado bônus demográfico) foi antecipado de 2023 para 2018. O envelhecimento populacional mais acelerado que o inicialmente previsto torna a reforma da previdência ainda mais imperativa para reequilibrar as contas públicas.

Mostramos, nesta primeira seção, o quadro geral das contas públicas. $\mathrm{Na}$ seção seguinte, discutiremos as saídas que têm sido apresentadas para restaurar o equilíbrio fiscal.

\section{PERSPECTIVAS PARA RESTAURAÇÃO DO EQUILÍBRIO FISCAL}

Não será trivial passar de um quadro de déficit público elevado e dívida crescente em proporção do PIB para um estado de superávit e endividamento estável ou decrescente. Dado o diagnóstico exposto na seção anterior, podemos concluir que será preciso avançar sobre um conjunto de medidas para que se possa restaurar o equilíbrio fiscal. Disso dependerá a continuidade do financiamento de melhores políticas públicas para a sociedade. Sem equacionar o déficit público, os custos para financiar novos aumentos na dívida pública deverão ser a cada ano maiores, com juros crescentes, volta do risco inflacionário, redução da renda real e limitações relevantes ao crescimento econômico.

O teto de gastos públicos foi importante para recolocar o equilíbrio fiscal como a prioridade do país. Ao estabelecer que a despesa só poderá ficar, no máximo, em nível equivalente à despesa de 2016 acrescida da inflação, ano a ano, o teto de gastos carrega implicitamente um ajuste que representa algo como R \$ 300 bilhões. Ele seria suficiente para estabilizar a relação dívida bruta/PIB em patamar inferior a $90 \%$ por volta de 2023 . O desafio está em promover as reformas e mudanças necessárias para o cumprimento desses objetivos.

Um ajuste dessa dimensão requer mudanças nas principais despesas obrigatórias, sobretudo na previdência social, além de alterações nos gastos com pessoal e melhor focalização dos gastos sociais. Apesar dos distintos arranjos tecnicamente possíveis, o avanço dessa agenda depende, eminentemente, da economia política do país, uma vez que diversos temas demandam mudanças constitucionais ou legais.

A Instituição Fiscal Independente (IFI) concebeu um conceito que ajuda a compreender a importância de debater as reformas no gasto obrigatório. Trata-se 
da margem fiscal. Dada a limitação para o crescimento do gasto público primário, a IFI projeta cada uma das principais rubricas de despesa: previdenciária, assistencial, abono salarial e o seguro desemprego, os subsídios e subvenções, o Bolsa Família, dentre outras. As projeções levam em consideração diversos cenários macroeconômicos e fiscais, como, por exemplo, a realização de reforma previdenciária mais ou menos ambiciosa. Uma vez projetadas as principais rubricas do gasto público, dado o limite máximo estabelecido pelo teto, a margem fiscal é calculada por diferença.

Composta por investimentos, inclusive do PAC, e despesas com custeio de políticas públicas e dos ministérios, a margem fiscal representa uma melhor aproximação do efetivo grau de flexibilidade do gasto público. Em 2017, a margem fiscal foi estimada em R $\$ 133$ bilhões (Gráfico 7) e, de acordo com as projeções da IFI, em resposta a uma série de vinculações legais e constitucionais presentes no orçamento público, a margem fiscal estimada para este ano será reduzida para R \$ 110 bilhões ou apenas 8,2\% da despesa. O grau de liberdade, como se vê, é extremamente reduzido.

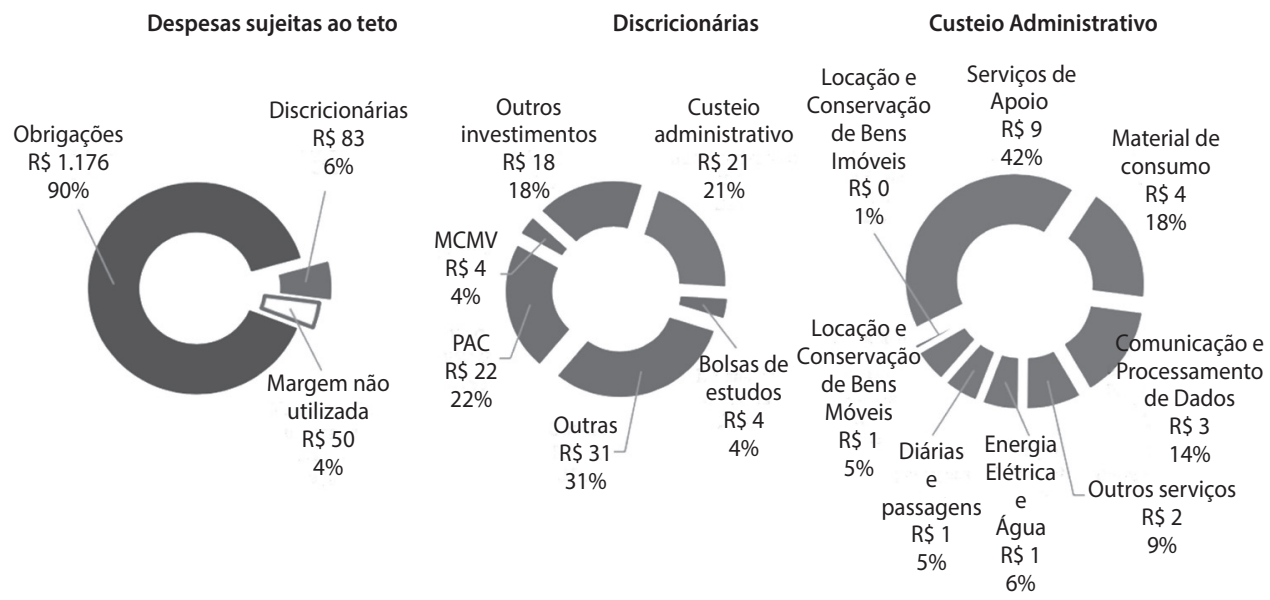

\section{Gráfico 7 - Composição da Margem Fiscal da União em 2017}

Fonte: IFI.

O tímido avanço das reformas estruturais pelo lado do gasto, notadamente obrigatório, pressiona negativamente a margem fiscal. Isso porque, para reduzir o déficit público não financeiro, a variável de ajuste de curto prazo acaba sendo a margem fiscal, particularmente, os investimentos. Percebe-se, portanto, que a maneira mais eficiente e sustentável de ampliar os investimentos públicos é justamente controlar a taxa de crescimento das despesas obrigatórias, em benefício do processo de consolidação fiscal. 
O estrangulamento dos investimentos e a limitação para executar políticas públicas são decorrências, portanto, da falta de controle do gasto obrigatório e não da instituição da regra para o crescimento das despesas. Vale revisitar que antes da aprovação do teto de gastos, em 2015 por exemplo, já havia distintos sinais de dificuldade na execução de gastos dessa natureza, justamente em função da redução do gasto discricionário como forma de reduzir o tamanho do déficit fiscal.

A instituição do teto de gastos explicitou para os órgãos públicos, parlamento e toda a sociedade a restrição orçamentária do governo. De forma semelhante a uma família que vive além de suas posses e acumula déficits e dívida, assim vive o país. A insustentabilidade desse arranjo fiscal é questão matemática, livre de qualquer concepção ideológica. A maturidade para reconhecer a gravidade do problema e impor um limite para o crescimento de gastos traz consigo a eleição de prioridades e escolhas, para cada órgão e Poder da República.

Apesar da semelhança ilustrativa com o orçamento familiar, o desequilíbrio das contas públicas é muito mais grave, pois afeta uma série de preços e variáveis econômicas como a inflação, a taxa de juros, os investimentos, o nível de emprego e renda, a desigualdade, e a violência, etc. Não custa lembrar que o desequilíbrio fiscal financiado por elevação de dívida terá que ser pago no futuro não apenas por nós mesmos, mas pelas próximas gerações. Há, portanto, um conflito entre gerações subjacente à questão fiscal.

O exemplo mais evidente desse conflito pode ser dado através da previdência social. Apesar de o Brasil ser um país jovem, por enquanto, conforme vimos na perspectiva de evolução da razão de dependência, seu gasto previdenciário total (da união, estados e municípios) já é muito elevado, da ordem de 13\% do PIB, maior do que o país mais velho do mundo, o Japão. Com a mudança rápida no quadro demográfico do país, nos próximos anos e décadas, mantidas as regras atuais, o país terá um gasto previdenciário ainda mais elevado e que terá que ser pago de alguma maneira: inflação, carga tributária ou mais dívida pública.

A reforma da previdência, apesar de imperativa, não deve ser suficiente para reverter o grave quadro de desequilíbrio fiscal. Conforme projeções da IFI, mesmo no cenário em que uma reforma importante da previdência seja aprovada, o desafio de inicialmente controlar e posteriormente reduzir a dívida pública será grande. No cenário base da IFI, considerado o mais provável, mesmo com a aprovação da reforma da previdência e a alteração da regra do salário mínimo para manutenção de seu atual poder de compra (sem reajustes reais), a dívida pública continuará crescendo no próximo mandato e deve estabilizar-se apenas em 2023, no patamar de $84,1 \%$ do PIB, sob hipótese de cumprimento do teto de gastos (Gráfico 8). Na melhor das hipóteses, a dívida só começa a cair no final do próximo mandato. 


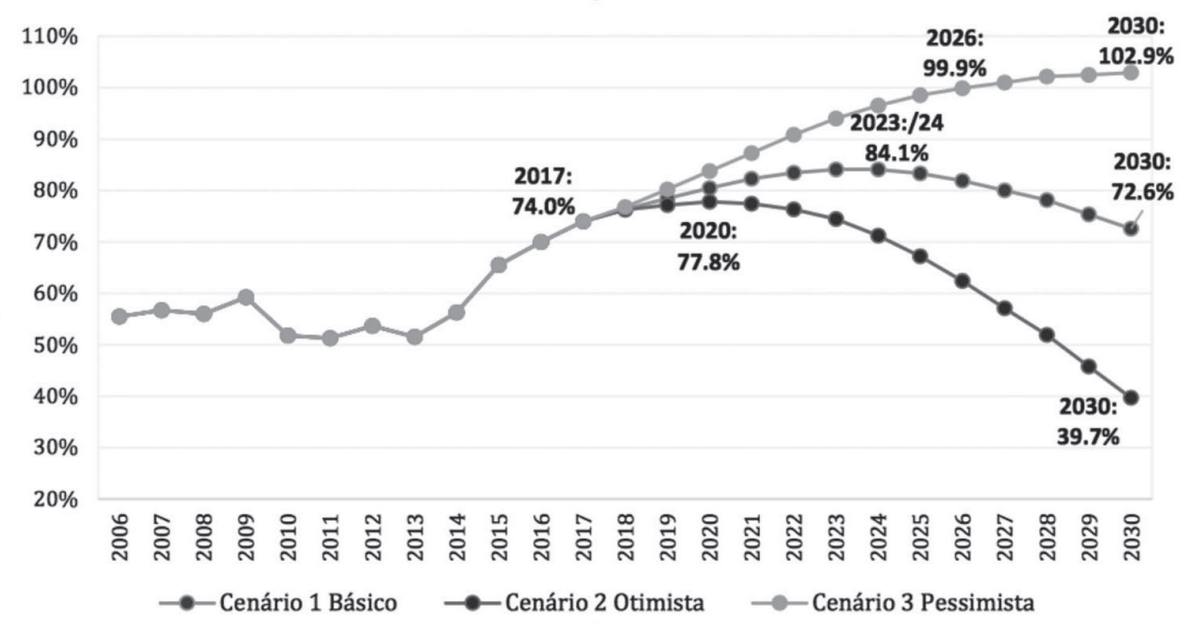

\section{Gráfico 8 - Cenários para a Dívida Bruta do Governo Geral (em \% do PIB)}

Fonte: IFI.

A velocidade de ajuste implícita no teto de gastos é gradual e continuada, sem um choque inicial. O seu atingimento, conforme destacamos, exigirá reformas no gasto obrigatório para além do previdenciário e deve incluir as outras rubricas mais importantes de gasto, como os salários de servidores ativos e benefícios pagos a aposentados e pensionistas do setor público, bem como os gastos sociais. O trabalho de reavaliação do gasto público é fundamental, inclusive, para efeito de ampliação da equidade e maior eficiência das políticas públicas, conforme largamente explicitado pelo Banco Mundial (2017) em trabalho recente. Vale notar que, mesmo no tocante à execução de políticas sociais, há notável espaço para ampliação de sua eficiência e focalização para as pessoas que realmente mais precisam do suporte governamental.

O sucesso de um amplo programa que seja capaz de reequilibrar as contas públicas deve, portanto, reduzir o gasto público e melhorar sua qualidade. A pressão estrutural para o avanço das despesas em nível superior à capacidade de geração de riqueza do país precisa ser contida. Nesse sentido, é fundamental cumprir a regra de gastos.

De acordo com as projeções da IFI, a realização de uma reforma da previdência contribui para o cumprimento do teto de gastos até 2020. Isso não quer dizer que o ganho com a atualização das regras previdenciárias seja pouco producente, mas apenas que, em razão de seu ganho ser modesto no início e cada vez maior com o passar do tempo, há um descasamento entre a redução de gastos necessária para cumprir o teto e os dividendos gerados pela reforma no curto prazo. O cumprimento da regra constitucional, portanto, exigirá reformas em 
outras rubricas do gasto público, permitindo assim que a margem fiscal composta por investimentos e pela execução de políticas públicas pelos ministérios seja mantida e, eventualmente, ampliada. A trajetória da margem fiscal em diferentes cenários pode ser identificada no Gráfico 9.

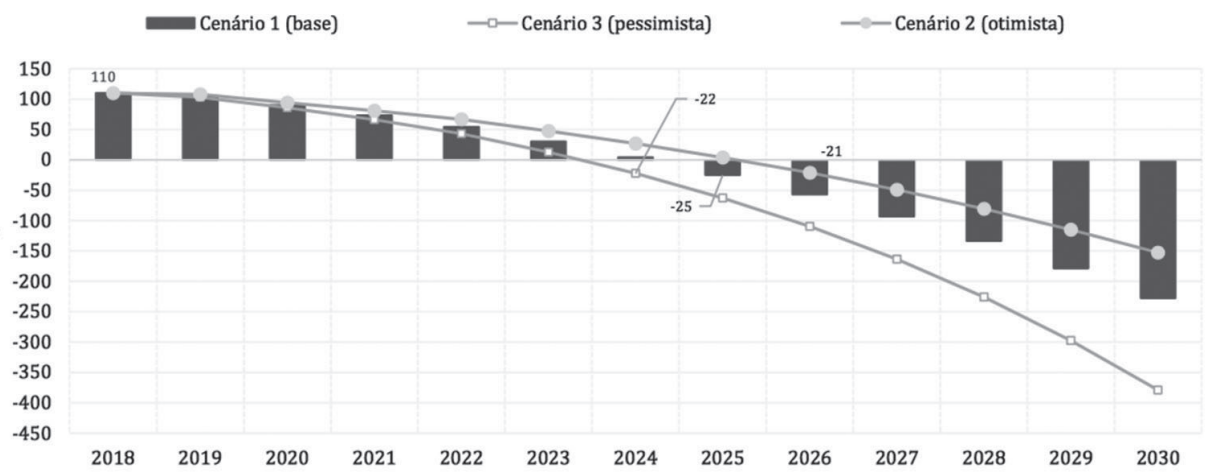

\section{Gráfico 9 - Evolução da Margem Fiscal (em R\$ Bilhões)}

Fonte: IFI.

O gráfico 9 revela que, mesmo na presença da reforma da previdência, será necessário promover atualização em outras rubricas do gasto público como forma de, não apenas cumprir a regra constitucional, mas também promover maior equidade e eficiência no gasto público. O sucesso na promoção dessas reavaliações contribuirá para a reversão de déficit primário, bem como para estabilização e posterior recuo do elevado nível da dívida pública do país.

A alternativa ao ajuste concentrado no lado das despesas é a elevação de receitas através do aumento da carga tributária. Não optar por nenhum desses caminhos significará optar automaticamente pelo ajuste via aumento da dívida e, concomitantemente, da inflação. O financiamento do nível de gastos além da capacidade de geração de riqueza e arrecadação do governo, através de aumento sistemático da dívida pública, tem limites. Sem perspectiva de reequilíbrio das contas, o risco de crédito público aumenta continuamente e se deteriora, de maneira que há limites para o financiamento do déficit via maior dívida. Nesse cenário, o maior risco de calote ou dificuldades de pagamento afeta a percepção dos agentes econômicos, que ficam cada vez mais avessos à rolagem desses déficits ou, quando aceitam financiar o excessivo gasto do governo, cobram juros mais elevados em resposta ao risco crescente de não recebimento futuro.

O efeito prático de tudo isso é que essa maior percepção de risco e falta de horizonte de reequilíbrio das contas provoca uma saída de recursos ou indisposição em rolar novos déficits do governo, com impactos sobre a taxa de câmbio que 
fica mais desvalorizada. A perda de valor da moeda doméstica produz efeitos inflacionários, de maneira que a inflação é uma consequência direta e imediata da ausência de perspectiva de correção do desequilíbrio fiscal. É preciso ter claro que só há três formas de financiar políticas públicas: emitindo moeda, como dissemos ao início desse capítulo, cujo efeito colateral é mais inflação; emitindo títulos públicos, cujo custo são os juros que incidem sobre uma dívida mais elevada; e criando ou aumentando tributos, cujo custo é o chamado peso morto (efeito negativo do imposto sobre a atividade econômica e o bem-estar da economia).

O Brasil optou, nos últimos vinte anos, por ajustes sistemáticos pelo lado das receitas, com aumento de carga tributária. Esse canal, todavia, apresenta espaço cada vez mais reduzido, pois o país já possui uma elevada carga tributária, em torno de $32 \%$ do PIB, sem contar a enorme complexidade e desincentivo para um bom ambiente de negócios, com regras simples, claras e horizontais. Estudos internacionais revelam ainda que é mais eficiente e positivo para a economia produzir ajustes pelo lado da despesa do que da receita.

As discussões sobre a reforma tributária têm crescido no Brasil. Além da necessidade de reduzir a grande complexidade e iniquidade associadas a uma série de regimes especiais de tributação, onde as pessoas de menor renda acabam pagando proporcionalmente mais do que os mais ricos, existem outros vetores no debate tributário. É amplamente conhecido que o país tributa relativamente menos a renda e o patrimônio do que o consumo, quando comparado com diversos países, inclusive a média verificada entre os países-membros da OCDE. Há ainda uma discussão em torno da tributação de empresas e sua relação com a isenção dos lucros e dividendos, movimento que ganhou força em razão de países como os EUA e Argentina, por exemplo, terem reduzido a tributação e pelo fato do Brasil ser um dos poucos países que isentam este tipo de operação.

Não é trivial, contudo, partir para esse caminho antes de pensar seriamente sobre as mudanças a serem realizadas no gasto público, incluindo alterações que envolvam ganhos de eficiência e equidade, com efeito fiscal relevante e legitimador sobre as reformas estruturais fundamentais. A curva de Laffer, uma referência importante para discutir o tamanho da carga tributária nos países, indica que há sempre um ponto de máximo, em termos de tributação, a partir do qual incrementos na carga tributária podem levar à redução na arrecadação. Em suma, é absolutamente importante pensar a solução econômica e tributária à luz dos incentivos que estão sendo contratual e legalmente colocados para os agentes econômicos.

\section{CONCLUSÕES}

Não há solução fácil para corrigir o agudo desequilíbrio das contas públicas no país. O Brasil que hoje tem um déficit primário de aproximadamente $2 \%$ do 
PIB, precisa fazer um resultado positivo (superávit) de algo em torno de $2 \%$ a $2,5 \%$ do PIB para estabilizar a relação dívida/PIB. Assim, a virada fiscal necessária apenas para estabilizar a elevada dívida pública é de 4 a 4,5 pontos percentuais do produto, equivalente a mais de $\mathrm{R} \$ 300$ bilhões.

Diante da magnitude desse desafio, é difícil que apenas correções pelo lado do gasto sejam suficientes. Tal limitação, todavia, não deve minimizar a necessidade de atacar o problema estrutural por trás do desequilíbrio fiscal: a velocidade de crescimento das despesas incompatível com a capacidade de geração de renda e riqueza do país. A qualidade da consolidação fiscal importa e, nesse sentido, distintas estratégias para equalizar o problema fiscal afetam as expectativas dos agentes econômicos e, consequentemente, os preços da economia como a taxa de juros, o nível de investimento e crescimento econômico, de emprego e renda, inflação, dentre outros.

O ponto de partida desafiador e a visão comparada internacionalmente impõem senso de urgência para solução do problema fiscal. Além de o país já apresentar uma das maiores dívidas, em um grupo de pelo menos 40 economias emergentes, as novas projeções populacionais do IBGE revelam que o país perdeu cinco anos em termos de bônus demográfico. Previsto inicialmente para terminar em 2023, as novas projeções apontam que o bônus demográfico acabará em 2018. O fim desse bônus terá consequências negativas do ponto de vista previdenciário, de produtividade e crescimento da economia.

A literatura internacional revela que países mais velhos possuem uma produtividade menor e, por sua vez, têm menor potencial de crescimento. Da mesma forma, a poupança de países mais idosos é menor do que a de países mais jovens, de acordo com a própria teoria do ciclo de vida. Por essa razão, o envelhecimento populacional imporá diversas restrições e desafios ao país.

Essas mudanças estruturais na demografia do país poderão limitar o espaço para ampliação de outras políticas meritórias como a redução da desigualdade, melhoria da qualidade da educação, da saúde, do saneamento, da segurança pública, dentre outras, caso o financiamento do Estado brasileiro não seja reequilibrado. As mudanças no nível de competição global, com mais inovação, tecnologia e requisito de capital humano de alta qualidade são ainda novos fatores que reforçam a necessidade de endereçar antigos e velhos problemas não resolvidos ou parcialmente solucionados no país. Os desafios são múltiplos, complexos e determinantes para o futuro do Brasil. Não temos tempo a perder.

\section{REFERÊNCIAS}

BANCO MUNDIAL. "Um ajuste justo - análise da eficiência e equidade do gasto público no Brasil”. Novembro. 2017. Acesso em: https://www.worldbank.org/pt/ country/brazil/publication/brazil-expenditure-review-report 
BARROS, G. L. de \& Afonso, J.R.R. "Receitas de Dividendos, Atipicidades e (Des) Capitalização”. Nota Técnica - FGV/IBRE. 2013. Acesso em: https://www. joserobertoafonso.com.br/dividendos-e-descapitalizacao-afonso-barros/

BARROS, G. L. de \& Afonso, J.R.R. "Sobre 'fazer o cumprimento' da Meta de Superávit Primário de 2012”. Texto para Discussão - FGV/IBRE. 2013. Acesso em: http://bibliotecadigital.fgv.br/dspace/handle/10438/11675

BARROS, G. L. de. "Resultado fiscal estrutural: visões metodológicas e aplicações para o Brasil”. Dissertação de Mestrado - FGV/EPGE. 2017. Acesso em: http:// bibliotecadigital.fgv.br/dspace/handle/10438/21983

BOGDANSKI, J., TOMBINI, A \& WERLANG, S. “Implementing Inflation Targeting in Brazil”. Banco Central do Brasil. Working paper n. 1. Julho de 2000. Acesso em: https://www.bcb.gov.br/pec/wps/ingl/wps01.pdf

BRASIL. Legislação. Emenda Constitucional n. 95/2016. Acesso em: http://www. planalto.gov.br/ccivil_03/constituicao/emendas/emc/emc95.htm

BRASIL. Legislação. Resolução do Senado Federal n. 42/2016. Acesso em: https:// www12.senado.leg.br/ifi/sobre

CARLIN, W. \& SOSKICE, D. “Macroeconomics: Imperfections, Institutions, and Policies”. Oxford. 2006.

INSTITUIÇÃO FISCAL INDEPENDENTE. Senado Federal. Relatório de Acompanhamento Fiscal (RAF) de abril de 2017. Acesso em: http://www2.senado.leg. br/bdsf/bitstream/handle/id/529486/RAF_abr17_pt3.pdf?sequence=10

NÓBREGA, M. \& SALTO, F. "Contabilidade criativa turva meta fiscal”. O Estado de S. Paulo, 30 de novembro de 2009. Acesso em: https://www.estadao.com.br/noticias/ geral,contabilidade-criativa-turva-meta-fiscal, 474130

PELLEGRINI, J. Brasil, Economia e Governo. 2013. Artigo em página eletrônica. Acesso em: http://www.brasil-economia-governo.org.br/2013/10/14/divida-liquida-dosetor-publico-decrescente-significa-politica-fiscal-sob-controle/

PELLEGRINI, J. Instituição Fiscal Independente. Senado Federal. Estudo Especial n. 03: "As operações compromissadas do Banco Central". Outubro de 2017. Acesso em: http://www2.senado.leg.br/bdsf/bitstream/handle/id/533520/Estudo_ OpCompromissadas.pdf

SALTO, F. \& ALMEIDA, M. "Finanças públicas: da contabilidade criativa ao resgate da credibilidade”. Editora Record, 2016. 